\title{
New technology for mineral deposits prediction to identify prospective areas in the Zhezkazgan ore region
}

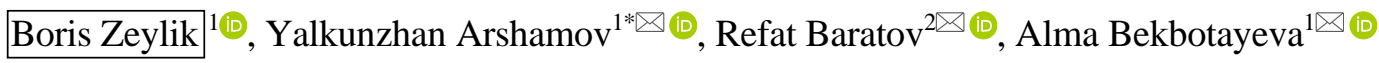 \\ ${ }^{1}$ Satbayev University, Almaty, 050010, Kazakhstan \\ *Corresponding author: e-mail y.arshamov@ satbayev.university, tel. +77078173582
}

\begin{abstract}
Purpose. Exploration and predicting the prospective areas in the Zhezkazgan ore region to set up detailed prospecting and evaluation works using new integrated technologies of prediction constructions in the mineral deposits geology.

Methods. An integrated methodological approach is used, including methods for deciphering the Earth's remote sensing (ERS) data, the use of geophysical data and methods of analogy and actualism. All constructions are made in accordance with the principles of shock-explosive tectonics (SET). Prediction constructions are started with the selection of remote sensing data for the studied region and interpretation based on the processing of radar satellite images obtained from the Radarsat-1 satellite. The radar satellite images are processed in the Erdas Imagine software package.

Findings. New local prospective areas have been identified, within which it is expected to discover the deposits. Their reserves are to replenish the depleted ore base in the Zhezkazgan region. Area of the gravity maximum 1 (the Near), considered to be the most promising, is located in close proximity to the city of Zhezkazgan; area of the gravity maximum 2 (the Middle); area of the gravity maximum 3 (the Distant-Tabylga); area of the gravity maximum 6 (the Central). A prospective area has been also revealed, overlaid by a loose sediment cover and located inside the Terekty ring structure, as well as the area of a thick stratum of pyritized grey sandstones, which is adjacent to the Sh-2 well drilled to the south of the Zhezkazgan field.
\end{abstract}

Originality. The use of a new prediction technology, in contrast to the known ones, is conditioned by the widespread use of the latest remote information from satellite images, which increases the accuracy of identifying the prospective areas of fields.

Practical implications. The new technology for predicting mineral deposits makes it possible to significantly reduce the areas exposed to priority prospecting, which provides significant cost savings.

Keywords: mineral deposits prediction, cosmogenic ring structures, concentric zones, superimposed blocks, gravimetry

\section{Introduction}

It is well known that in the last 2-3 decades in Kazakhstan, which is considered a country rich in mineral resources, nevertheless, there is an acute problem of singleindustry cities (Zhezkazgan, Balkhash, etc.) that appeared on the basis of large deposits discovered in the last century. The depletion of reserves and their complete development pose a threat to these cities. The situation has also worsened due to a sharp decline in prospecting operations. Therefore, for the accelerated replenishment of the mineral resource deposits base in these cities, it is necessary to set up prospecting operations using new technologies. In this regard, the authors propose a new technology for regional and local mineral deposits prediction, based on the principles of shock-explosive tectonics (SET), geophysical data and Earth's remote sensing (ERS) data in the Zhezkazgan ore region .
The scientific significance of the new prediction technology is substantiated by the widespread use of the latest remote sensing data obtained from the satellite images [1], [2]. The mineral deposits should be predicted using satellite images in conjunction with the vast data on the location of known metal and other deposits of minerals in the geological space as well as technogenic mineral resources [3], [4]. There is a great variety of both on the territory of Kazakhstan. The spatial position of the known deposits determines certain patterns. Therefore, the deposits that have not yet been identified and "waiting" to be discovered, of course, have to comply with these patterns. The new technology, based on the use of space information, unknown before the onset of the space age, allows, using simple techniques, to identify these patterns and rely on them in modern prediction constructions. The scientific significance of the proposed technology is covered in numerous publications [5]-[8] and has been patented [9]. 
The main idea of the new technology is to minimize the areas that require costly, thorough prospecting and exploration geological operations. Nowadays, there are many improved geophysical and geochemical methods. They should be used while sampling not over large areas, as it was before (as in the case of metallometric surveys), but over small areas, specially designated in accordance with the new technology, which should be covered with regular sampling (at regular intervals). Funds released as a result of reduction in the area of exploration, represent direct savings. Some of these funds can be directed to a detailed study of the spaces that are considered the most prospective from the point of view of new technology.

In accordance with the fluid-dynamic concept of the mineral deposits formation, presented by B.A. Sokolov and V.I. Starostin [10], it could be assumed that the structural control that is set for example for hydrocarbon deposits should manifest itself in the spatial allocation of deposits of both metallic and non-metallic minerals, which are one way or another associated with hydrothermal activity, that is, with fluid-dynamic processes. It is logical to imagine that the penetration zones formed by endogenous processes, or with structures formed as a result of hits of cosmic bodies, can "fulfil" the most substantial ore-controlling role for the bulk of deposits associated with fluid-dynamic processes [1], [11]-[13]. In particular, special attention was paid to this in the research work under Program No. 16 of the Presidium of the Russian Academy of Sciences, carried out under the supervision of N.P. Laverov, Vice-President of the Russian Academy of Sciences, Academician of the Russian Academy of Sciences. Notable examples of confinement to giant impact craters with diameters of more than $100 \mathrm{~km}$ of the largest deposits of gold, nickel, impact diamonds and oil are represented in the monograph "Change of Environment and Climate: Natural and Associated Technogenic Disasters", edited by N.P. Laverov [14]. This is the Vredefort crater (South Africa), D-200 km, age 2.0 billion years: half of the world's gold reserves. S.A. Vishnevsky confidently associates the famous Witwatersrand Gold-Uranium Deposit with this giant crater, "which accounted for about half of all world gold production for many decades" [15]. This is Sudbury crater (Sudbury Basin in Canada), D 200 km, age 1.9 billion years: $1 / 3$ of the world's nickel reserves. The Popigai Crater (Russia), D-100 km, age 36 million years: a giant deposit of impact industrial diamonds exceeding artificial diamonds in their abrasive properties and twice as hard as diamonds from kimberlite and lamproite volcanic pipes. The Chicxulub crater (Mexico), D-180 km, age 65 million years: Campeche oil, 2/3 of Mexico's production.

The proposed new technology for predicting mineral deposits is based on the most important structural exploration factor, which was previously not taken into account, or was taken into account very limitedly. This factor is ring structures (RS) [1], [6], [16]-[18]. And, first of all, cosmogenic ring structures of various scales, which are accompanied by concentric zones of tension-decompression and compression of the geological environment [6], [9], [19], [20].

Research over the past decade shows that mineral deposit fields are often associated with ring structures, both endogenous [16]-[18], [21], [22] and exogenous [1]-[7], [23][26]. It is assumed that the ring structures, which are associated with many mineral deposits, are mostly the result of the bombardment of the Earth by meteorites, asteroids and comets [27]. That is, these are structures of a cosmogenic, impact nature, representing huge volumes of brecciated and fractured rocks, which are natural pathways and structural traps for the penetration of ore-bearing mantle fluids, as well as liquid and gaseous hydrocarbons [9]-[13], [19], [28].

Local prediction of metallic mineral deposits based on the principles of shock-explosive tectonics and Earth remote sensing data for planning specific prospecting operations can and should be carried out within the boundaries of manifestation of cosmogenic ring structures of medium and small scales [29][32]. The diameters of these structures are measured from the first kilometres to tens of kilometres [23], [33]-[35].

Further in the paper, an attempt is made to determine the prospective areas to set up detailed prospecting and evaluation works using new technologies of prediction constructions in geology.

\section{Methods}

At the present stage, when the easily discovered deposits have almost completely run out, the need to develop a scientifically grounded theory for predicting and prospecting deposits, taking into account all the positive aspects of modern geological concepts, including shock-explosive tectonics, is of particular importance in increasing the efficiency of prospecting and exploration geological operations. The main research methods are methods for deciphering the Earth's remote sensing (ERS) data, the use of geophysical data and methods of analogy and actualism. A number of these methods, in turn, are complex. Prediction constructions are performed in accordance with the principles of shock-explosive tectonics (SET), which are repeatedly mentioned in numerous publications [1]-[8] and descriptions to the above patent [9].

The ERS data are deciphered in two stages: the selection of satellite images and their preliminary processing - visual interpretation with identification of the ring structures. The satellite images are selected based on availability. The Landsat-7 scanner images and Radarsat-1 radar images are used during the research. Images from the Radarsat radar satellite are processed in the ERDAS IMAGINE program, in which the necessary parameters are set (angle of the sun inclination, elevation of the relief, illumination, etc.) to develop a digital elevation model (DEM) of the terrain. Then, in the ArcGIS program, the Landsat image is combined with a digital elevation model for giving three-dimensionality (Fig. 1a).

Visual interpretation is carried out in the inset of satellite images at 1:500000 scale of the studied area. At the first stage, the geometric centres of six ring structures have been identified (Fig. 1b). Ring structures are the most important structural element in terms of regional and local prediction constructions and this phenomenon has almost never been used in geological constructions. The study of ring structures involves the widespread use of satellite images, which should be used in a comprehensive manner, in conjunction with large statistical information on the spatial allocation and extent of already known and explored various mineral deposits. It is obvious that the spatial allocation of each known deposit is a huge materialized information, resulting from the large economic expenditures. There should be no doubt that undiscovered deposits, "waiting" to be discovered, have to comply in their spatial allocation with the same patterns as the deposits already discovered. In this regard, the authors picture on a satellite image all the fields in the studied area (Fig. 1d). 
(a)

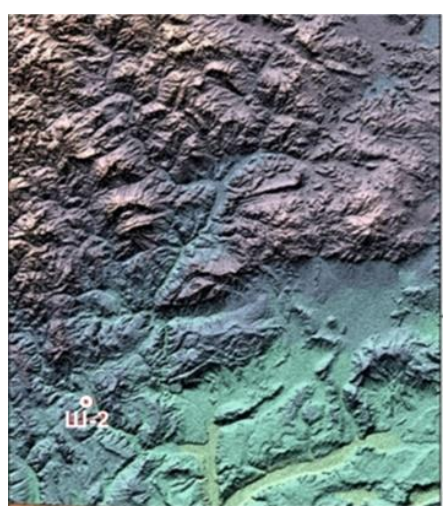

(d)

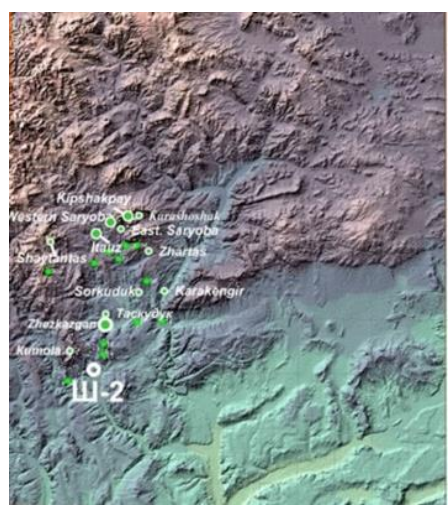

(b)

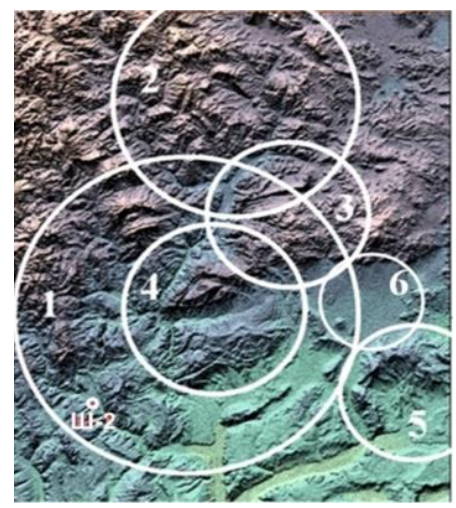

(e)

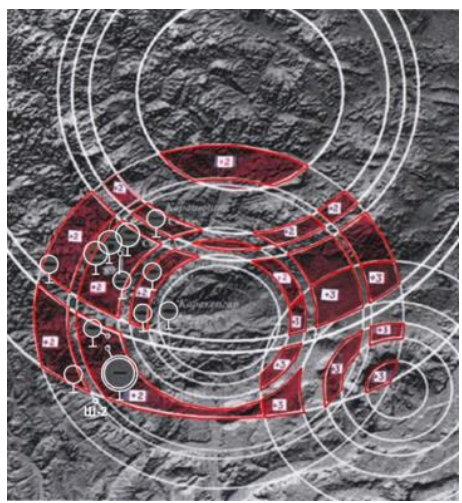

(c)

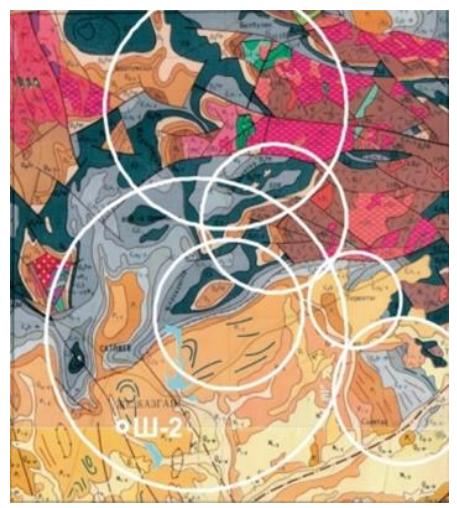

(f)

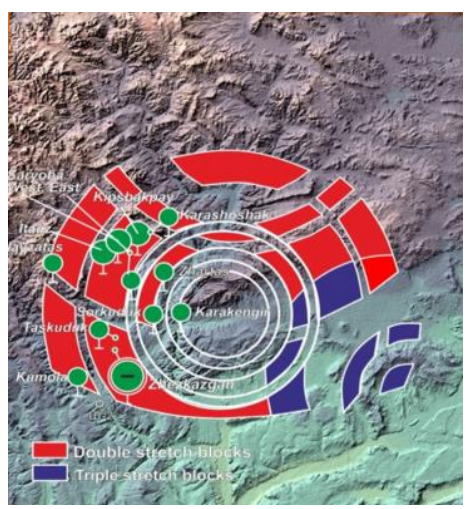

Figure 1. Prediction construction in the Zhezkazgan ore region: (a) the relief plotted based on the data of the radar satellite survey in the Zhezkazgan ore region and in its vicinities; (b) contours of the ring structures distinctively manifested in the relief of: 1 -Zhezkazgan; 2 -Northern; 3 -Middle; 4 -Karakengir; 5 -South-Eastern; 6 -Terekty; (c) contours of the ring structures on the Geological map of Kazakhstan at a scale of 1:1000000 [36]; (d) the Zhezkazgan ore region deposits, plotted on the relief according to the data of the Kazakhstan Mineral Map at a scale of 1:1000000: 12 small circles, the largest of them is the Zhezkazgan field; (e) concentric zones of tension and compression of the three ring structures: Zhezkazgan, Northern, South-Eastern, plotted considering the spatial position of the twelve known deposits; thickened contour of the Terekty ring structure; (f) blocks of double and triple tension in places of superimposition of the Zhezkazgan, Northern and South-Eastern ring structures

Then, in accordance with the principles of shock-explosive tectonics (SET), taking into account the spatial position of the known deposits in the area, concentric zones are drawn for all six ring structures (Fig. 1e and Fig. 2). The main purpose of distinguishing the concentric zones of ring structures is to identify the Earth's crust blocks with zones of increased fracturing and permeability for intensive hydrothermal solutions circulation. Therefore, they can be regarded as favourable "structural traps" for various mineral deposits. It is logical to assume that zones of permeability (hereinafter in the paper, decompression zones) are replaced by zones or blocks of compression, which are reflected on radar satellite images and digital elevation models as small hilly relief areas. Concentric zones of compression or tension of various ring structures can intersect and overlap each other regardless of their age, thereby creating a kind of interference of zones of compression or tension in some parts of the Earth's crust. Thus, according to numerous studies of the authors of this paper, the most prospective to explore new ore objects are the spaces located in the superimposed blocks of the extension-decompression zones of adjacent ring structures. The authors, using concentric zones of six ring structures of the Zhezkazgan region, have empirically identified the zones of increased permeability for the flow of hydrothermal processes. For more accurate local prediction of prospective areas, the authors of the paper have substantiated their prediction, based on a reliable geophysical exploration factor for the Zhezkazgan region.

\section{Results and discussion}

In this paper, as a specific example, the detailed prediction construction in the Zhezkazgan region is proposed in two options:

1. On the basis of ring structures, manifested in relief, taking into account their relatively young age.

2. On the basis of ring structures depicted in satellite images, but not manifested in the relief, that indicates their older age, combined with one of the structures manifested in the relief, but the morphological elements of which clearly contain and control all deposits of the Zhezkazgan ore region.

The Zhezkazgan ore region occupies the south-western corner of the Paleozoic basement of Central Kazakhstan. Its western border is the Turgai Depression, and its southern border is the plateau of the western half of Betpak-Dala in the Chu-Sary Su interfluve.

The geological structure of the region involves rocks of various ages and lithological composition, from Precambrian to Quaternary, sedimentary, metamorphic and intrusive. Numerous ore and non-metallic minerals are confined to them. Of the metal minerals in the region, there are deposits of iron, copper, lead, nickel, cobalt, gold, molybdenum, etc. [37]. Many of them were explored in different time and received the relevant assessment. Copper deposits are confined to various rock complexes, from the Precambrian to the Permian. The copper deposits, confined to the Zhezkazgan series 
of rocks, presumably corresponding in age to the Middle Carboniferous - Permian, are of greatest interest. The rocks of the Zhezkazgan series occupy large areas in the region. The wings of anticlinal and synclinal structures, as well as the cores of synclines and depressions are composed of them. The Zhezkazgan series of rocks 1030-1070 m thick consists of a complex of interstratified red and grey sandstones and, covering them, stratum of false-bedded red sandstones and siltstones [38].

\subsection{The first prediction option - on the basis of ring structures, manifested in the relief}

In the Zhezkazgan ore region and its vicinities, 6 ring structures are clearly manifested in the relief plotted according to the data of radar satellite survey (Fig. 1a, b). All the structures are imposed on a heterogeneous geological situation, which indicates their exogenous (cosmogenic, impact) nature (Fig. 1c). Within the contours of the zones of impact wave influence of these ring structures, there are 12 known fields, including the largest of them - Zhezkazgan field (Fig. 1d, e). Given the distinguished ring structures, based on the spatial allocation of known deposits, the tension and compression zones of three ring structures have been constructed - Zhezkazgan and Northern as the most significant in size, which are cometary, without craters, and SouthEastern, which is asteroidal, with a crater (Fig. 1b, d, e, f).

Superimposition of tension and compression zones makes it possible to distinguish the blocks of double tension and 8 blocks of triple tension, covering the most prospective areas located in the eastern and south-eastern parts of the Zhezkazgan ore region (Fig. 1e,f). Over time, prospecting operations should be set up within all 8 triple tension blocks. As can be seen, these constructions do not take into account all ring structures identified in the relief. In addition to the unaccounted for Middle (structure 3), Karakengir (structure 4) and Terekty (structure 6), in the southern and southeastern parts of the region, the ring structures are marked with arched valleys of temporary streams, and their centres are outside the territory covered in the presented figures. If necessary, for more detailed prediction constructions, these structures can also be taken into account.

We consider it is very important to use gravimetric data in these prediction constructions. It should be emphasized that M.K. Satpayeva, who studied the area under consideration for a long time and drew attention to the control of the Zhezkazgan ore region deposits by ring structures of various diameters, has pointed out the need for using gravimetric survey data [38]. The authors share this point of view.

Analysis of the deposits allocation on the gravimetric map, specifically on the map of the residual anomalies $\Delta g$ at 1:500000 scale, shows that the Zhezkazgan ore deposits (a very large field) and Zhaman-Aybata (a large field) are within the contours of relative gravity maxima. In this regard, the gravity maxima of this region deserve careful attention.

In Figure 2, six gravity maxima are outlined. The Zhezkazgan field (very large) itself and two small Taskuduk and Zhezdy fields are in the contour of maximum (the Western). In addition, five more maxima, closest to Zhezkazgan, are outlined. They are given names and numbers: gravity maximum -1 (the Near), gravity maximum -2 (the Middle), gravity maximum -3 (the Distant), gravity maximum -4 (the South-Eastern). The Western gravity maximum is assigned with number 5. It is the most thoroughly studied. In the centre of the triangle formed by the three gravity maxima of Near, Middle and Distant, there is one more gravity maximum. It is called the Central. It is assigned with number 6. This maximum also deserves attention, although it is somewhat of an inferior in intensity to the above mentioned three maxima.

A primary serious attention should be paid to gravity maximum, which is large in area, the central part of which is located at a distance of $20-22 \mathrm{~km}$ to the east of the Zhezkazgan city, and $40-45 \mathrm{~km}$ from the central part of the Western gravity maximum, containing the Zhezkazgan field and the fields of Taskuduk and Zhezdy. This is a gravity maximum -1 (the Near). Its centre is located at $47^{\circ} 42^{\prime} \mathrm{N}$ and $68^{\circ} 00^{\prime} \mathrm{E}$. The area covered by the maximum is about $200 \mathrm{~km}^{2}$.

The gravitational situation observed here allows to hope for the discovery of a large ore object (the second Zhezkazgan?) located at a depth. This maximum, according to the intensity values characterizing it, exceeds the maximum - 5 (the Western), in the contour of which there are very large Zhezkazgan field and small Taskuduk and Zhezdy fields, as well as a maximum - 4 (South-Eastern), to which the large Zhaman-Aybat field and the small Taskura field are confined. It is known that ore bodies at Zhaman-Aybat field are located at depths of 400-700 m.

It should be noted that the centre of the gravity maximum 1 (the Near) is located at the shortest distance from the city of Zhezkazgan, only $20-22 \mathrm{~km}$, and a railway passes through it. This is rather essential technical-and-economic factor.

On these areas, limited in size and distinguished with the help of the proposed innovative prediction method, it is necessary to conduct research with the use of modern geophysical and geochemical methods. In particular, on these areas it is necessary to set up and conduct a "deep" form of geochemical exploration - geochemistry of the mobile form method - MFM, etc. Since, as previously noted, the Zhezkazgan ore fields (a very large field) and ZhamanAybata (a large field) are located within the contours of relative gravity maxima, then it is natural to analyse the spatial position of all fields in the Zhezkazgan ore region within the gravitational field. The entire region is located in a gravitational field with an intensity from -36 to $+8 \mathrm{mGl}$ [39].

Figures 2 and 3 show the location of the distinguished gravity maxima and their correlation with the concentric zones of tension and compression of three ring structures (Zhezkazgan, Northern and South-Eastern) found in the studied region. A very large Zhezkazgan field is located in a distinctively manifested relative gravity maximum, mentioned above as the Western. A small Taskuduk field is located within the contour of the same maximum. Both of these fields are located in the north-eastern part of this, significantly large in area, gravity maximum, outlined by the isoline of $-4 \mathrm{mGl}$. The Zhezkazgan itself is located within this maximum on a relatively small area, which is outlined by the isoline of $-2 \mathrm{mGl}$. In a similar situation, that is, near a small maximum in area, with the same intensity of $-2 \mathrm{mGl}$, there is a small Zhezdy field, located to the south-west of the Zhezkazgan field. All three fields (Zhezkazgan, Taskuduk and Zhezdy) are located within the contour of a single gravity maximum, outlined by the isoline of $-4 \mathrm{mGl}$ (Fig. 2).

Thus, the geological data on the spatial allocation of known deposits, combined with geophysical data on the correlation of the fields in the region with geophysical anomalies, indicate the high perspective of the area, enclosed within these gravity maximum boundaries. 


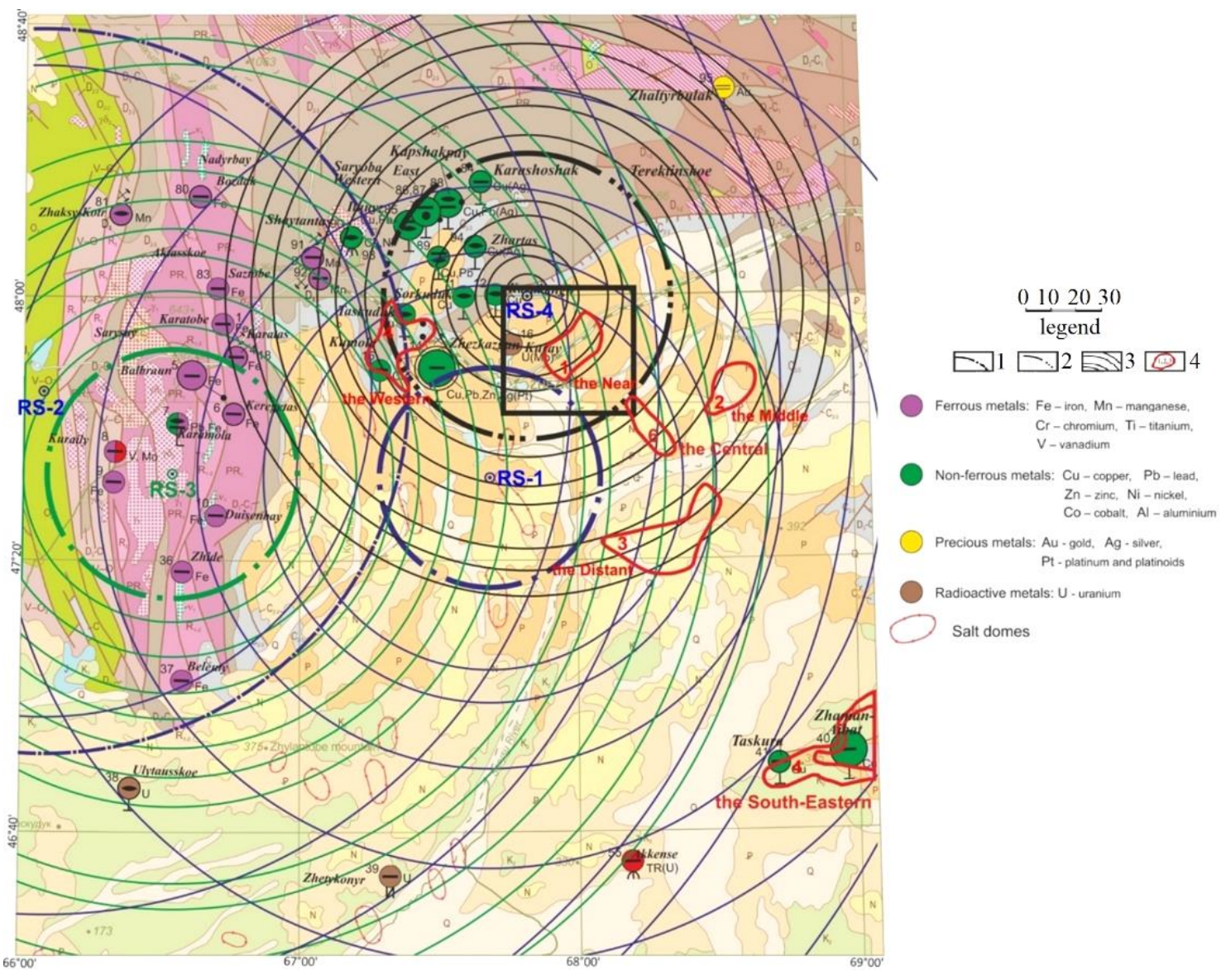

Figure 2. Fragment of the Kazakhstan minerals Map at 1:1000000 scale [40]: 1 - contours of ring structures (RS-1, RS-2 and RS-3), taken from the Cosmogeological Map of the USSR (10); 2 - contour of the Zhezkazgan ring structure (RS-4), clearly manifested in the relief; 3 - concentric zones of tension and compression, marked with the same color as the contour of each of these ring structures; 4 -contours of relative gravity maxima - 1, 2, 3, 4, 5, 6, within the boundaries of which the detailed exploration operations and exploration drilling should be set up. In the black square - the gravity maximum - 1 (the Near), which deserves the most careful attention of all at this stage of research

It should be taken into account that the area of the modern Zhezkazgan ore field itself is $62 \mathrm{~km}^{2}$ (very large). It should be noted that the central, inner part of this maximum, promising due to its confinement to the maximum, is intersected by narrow compression zones of the Zhezkazgan and Northern ring structures. At the point of their superimposition, a relatively small block of double compression is determined. However, a similar situation is typical for Western gravity maximum, which contains the Zhezkazgan, Taskuduk and Zhezdy fields (Fig. 2). This once again underlines the high perspective of the area enclosed in the contour of the Near gravity maximum.

The above constructions prove that within the entire gravity maximum Near, detailed modern geochemical and geophysical exploration operations should be performed with the use of the MFM method, etc., that is basic methods of geochemistry and geophysics should be applied.

The complex of planned detailed geophysical and geochemical works should be carefully thought out, prepared and performed. After this, drilling of exploration wells should be carried out. Drilling should come along with a detailed geophysical study of the near-wellbore area, since ore bodies are relatively narrow ribbons. The probability of a "fault" in this situation is very significant.

The distinct manifestation of all the above mentioned ring structures in the relief allows to assume their relatively young, probably Mesozoic-Cenozoic age, which casts doubt on their ore-controlling role for Paleozoic ore objects.

In this regard, an idea arises about similar prediction constructions based on older ring structures depicted in satellite images, but not manifested in the relief.

\subsection{The second prediction option}

The second prediction option is based on ring structures depicted in satellite images, but not manifested in relief, which suggests their older age, combined with a structure manifested in the relief, but definitely containing all the fields of the Zhezkazgan ore district.

The older age of the ring structures makes possible to suggest their considerable erosional destruction and, therefore, levelling process, disappearance of their intensity and manifestation in the relief. At the same time, erosional destruction, by removing the surface, clearly pronounced morphological peculiarities of these structures, inevitably outcrops their deep zones, represented by arcuate and radial faults, which are accompanied by thick flooded zones of crushing. These faults and zones of crushing are accentuated by vegetation and, therefore, clearly observed in satellite images, being not manifested or weakly manifested in the relief. For such structures, the hypothesis about their Paleozoic age, "conformable" to the Paleozoic age of the ore objects of this region, is more acceptable. 


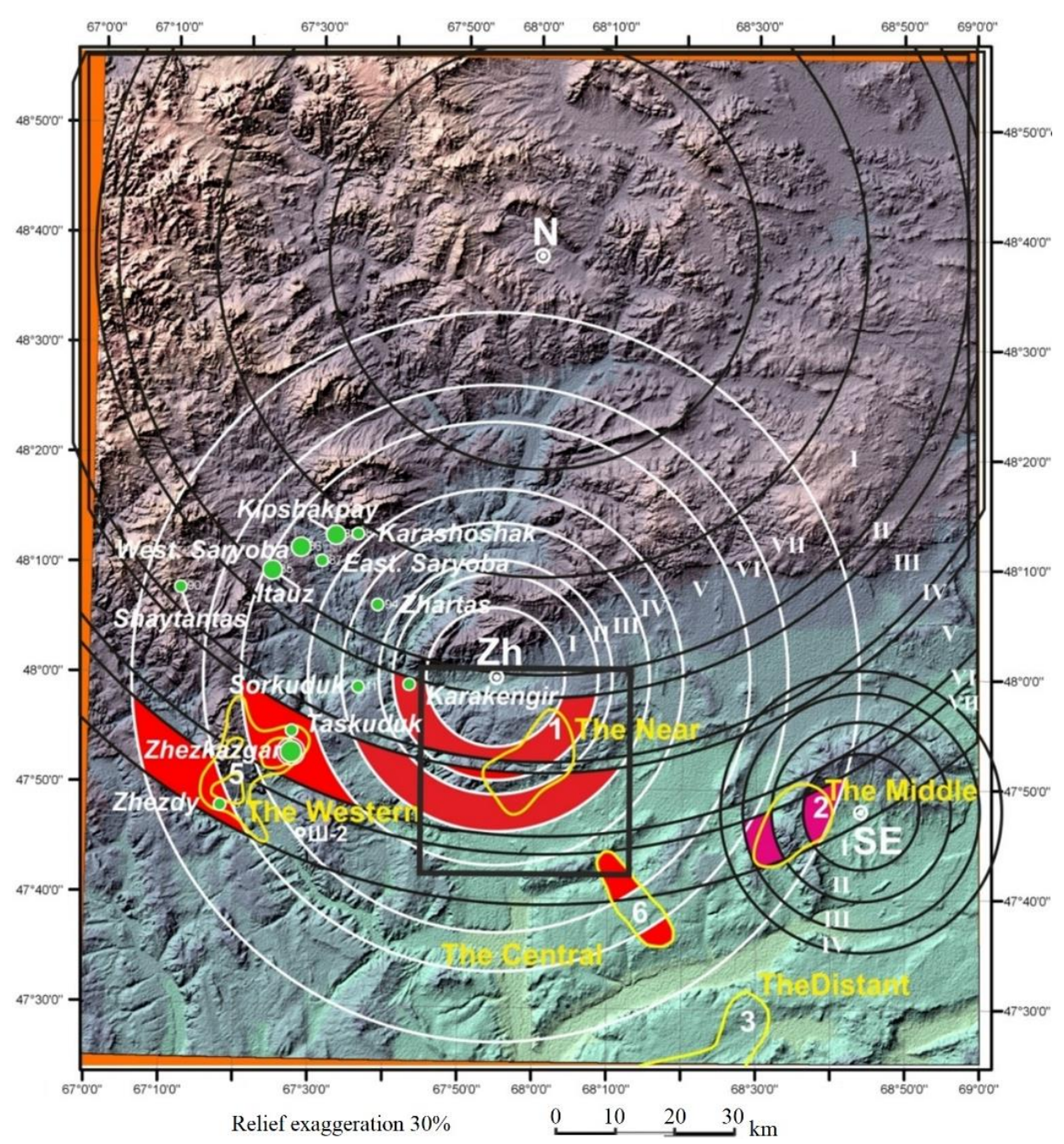

Figure 3. Ring structures, manifested in the relief, are plotted from the radar satellite survey data: Zhezkazgan (center - Zh), Northern $($ center - N) and South-Eastern (center-SE). Ring structures are accompanied by concentric zones of tension-decompression (denoted by odd Roman numerals) and compression (denoted by even Roman numerals). All the fields in the region are shown. The contours show gravity maximum - 1 (the Near), gravity maximum - 2 (the Middle), gravity maximum - 6 (the Central), gravity maximum - 3 (the Distant), and gravity maximum, containing the Zhezkazgan, Taskuduk and Zhezdy fields (the Western gravity maximum -5 )

Three such structures are taken from the Cosmogeological Map of the USSR [41]. These three structures are plotted on the Kazakhstan Mineral Map and are designated as RS-1, RS-2 and RS-3 (Fig. 2). RS-4 is taken as the fourth structure for prediction construction. This is the Zhezkazgan structure. Although it is clearly manifested in the relief, which was indicated above, it is admitted the possibility to use it, since all ore objects are located inside it, close to its centre. This suggests the possibility of their genetic relation.

In terms of prediction, as noted above, all mentioned relative gravity maxima (Near, Middle, Distant and Central) are of great interest. In this second option of prediction, as in the first one, the relative gravity maximum, which is located closer to Zhezkazgan than others, is the most interesting. This is maximum -1 (the Near).

Based on the spatial allocation of all the copper-ore deposits in the Zhezkazgan region and taking into account the spatial allocation of the centres of the four ring structures listed above, the concentric tension and compression zones have been constructed for each of them (Fig. 2). On the basis of superimposition of concentric zones of tension and compression of all four ring structures, blocks of the highest, medium and lowest tension-decompression and compression are determined. Figure 4 presents the differentiation of such blocks in the contour of the gravity maximum 1 - (the Near) in this option of prediction. As it can be seen, the gravity maximum 1- (the Near) is of particular interest in both prediction options provided.

Particular attention should be paid to the fact that in the contour of the gravity maximum 1 - (the Near), according to both prediction options, there are sections of superimposition and overlapping the tension areas of the geological environment.

It seems obvious to combine the two prediction options, that is, to impose one prediction option on the other, to maximize the reduction of prospective areas.

This superimposition is shown in Figure 5.

In addition to the gravity maxima mentioned above, the area of the Terekty ring structure (structure 6 in Figure 1b) deserves particular attention.

The Terekty ring structure is a depression filled with Early Quaternary loose sediments that are as an overlaying cover for possible ore objects hidden at some depth (therefore, the structure is accentuated). 


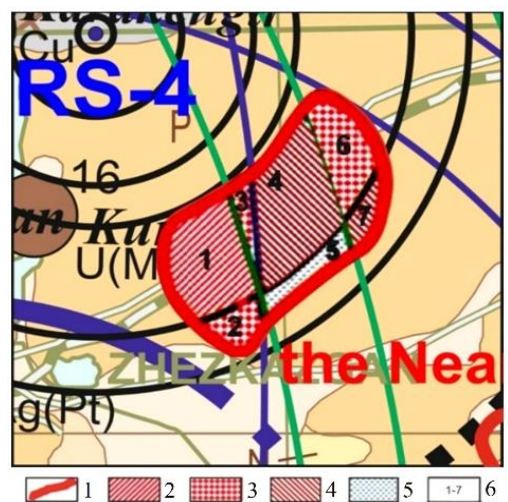

Figure 4. Fragment of the Kazakhstan Mineral Map outlined by a black square in Figures 2 and 3 [40]: 1 -contour of the gravity maximum - 1 (the Near); 2 - block of quadruple tension; 3 - blocks of triple tension and single compression; 4 - blocks of double tension and double compression; 5 - blocks of triple compression and single tension; 6 - block numbers inside the gravity maximum contour

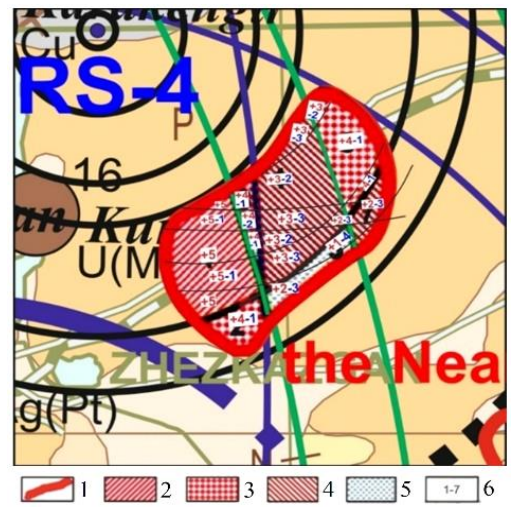

Figure 5. Fragment of the Kazakhstan Mineral Map: the result of superimposition of the prediction constructions for the first and second options is shown. The arcuate parts of the ring structures in the two options of prediction constructions are definitely different in the thickness of the lines. Blocks are distinguished, within which repeated paroxysms of tension and compression of the geological environment have arisen. Tension paroxysms are characterized by red numerals with a sign +. Compression paroxysms are characterized by blue numerals with a sign -. The most prospective blocks are those located in the western part of the Near gravity maximum with the values of tension and compression paroxysms +5 , as well as +5-1. As can be seen, the total area of these blocks is relatively small. There is no need to explore the entire area of the Near gravity maximum

The gravitational field in the depression contours is characterized by values of -12 and $-16 \mathrm{mGl}$, and its contours make possible to note a certain similarity of a separate gravity maximum. If to take into account that three medium deposits Itauz, West Saryoba and Kipshakpay are located in the gravitational field between the isolines from -18 to $-20 \mathrm{mGl}$, this object undoubtedly deserves serious attention!

The depression is mostly covered by Early Quaternary loose sediments shown on the Geological Map of Kazakhstan at 1:1000000 scale [36] (Fig. 1c) and the Kazakhstan Mineral Map at 1:1000000 scale [40]. The depression most probably is a meteorite crater, like ring structure 5 . Three blocks of triple tension fall on the depression (Fig. 1f). Inside the depression, there is the Terekty railway station, located $85 \mathrm{~km}$ to the east of the Zhezkazgan field.
The fragmentation of rocks, characteristic of crater funnels and contributing to the localization of hydrothermal processes, is an additional favourable ore-localizing factor, which draws attention to this prospective closed area. This fragmentation should be considered as an addition to the three cases of tension-decompression, which influences this area of the ore-bearing region.

The area adjacent to the Sh- 2 well drilled to the south of the Zhezkazgan field deserves serious attention. A thick stratum of pyritized grey sandstones has also been revealed (the well is shown in Figure 1a-d). In accordance with the proposed research methodology, based on the prediction constructions in 2002-2003, that is, 16-17 years ago, the Sh-2 well, located to the south of the Zhezkazgan ore field, was set by the first author. The well had a depth of $1500 \mathrm{~m}$.

It was drilled through fine-grained grey sandstones with pyrite nodules along plant remains at a depth from 1300 to $1395 \mathrm{~m}$. The pyrite nodules are evident signs of hydrothermal activity in the rocks of the ore-bearing Tuskuduk series. This is a highly informative positive sign of exploration. If to take into account that the thicknesses sequence in the section of the Tuskuduk ore-bearing series in the Zhezkazgan ore region is in the range of $200-350 \mathrm{~m}$, and, at the same time, grey sandstone with and without ore is alternating in the section with red sandstone, argillite and siltstone, then the intersection of a thick - $95 \mathrm{~m}$ - stratum of fine-grained grey sandstone with pyrite in the general section of the Tuskuduk series with a thickness of $205 \mathrm{~m}$, crossed by a well, should attract the closest attention. It is essential that this very important highly informative sign is found at a fairly large distance from the Zhezkazgan ore field $-11 \mathrm{~km}$. This indicates that the area, located south of the Zhezkazgan field is still prospective. It should be noted that the age range of mineralization in the studied region can be traced from the Lower Carboniferous (Itauz field) to the Lower Permian (Taskura field).

\section{Conclusions}

The research results make possible to distinguish the following objects in the Zhezkazgan ore district to conduct detailed prospecting and exploration operations:

1. The area of gravity maximum 1 (the Near), located in the immediate vicinity of the Zhezkazgan city (the centre of this area, as noted above, is only $20-22 \mathrm{~km}$ from it) and connected with it by railway, is considered the most promising.

2 . The area of gravity maximum 2 (the Middle).

3. The area of gravity maximum 3 (the Distant - Tabylga).

4. The area of gravity maximum 6 (the Central).

5. Particular attention should be paid to the area, overlaid by a loose sediment cover and located inside the Terekty ring structure, as well as the area adjacent to the Sh-2 well, drilled to the south of the Zhezkazgan field, where a thick stratum of pyritized grey sandstone is revealed at a depth.

Thus, the possibility of using a new prediction technology based on the principles of shock-explosive tectonics (SET), geophysical data and the use of the Earth's remote sensing (ERS) data for local prediction has been substantiated on the example of the Zhezkazgan ore region.

\section{Acknowledgements}

This research has been performed with financial support from the Committee of Science of the Ministry of Education and Science of the Republic of Kazakhstan (grant project No. AR05132942 for 2018-2020). 


\section{References}

[1] Baibatsha, A.B., Bekbotayeva, A.A., \& Mamanov, E. (2015). Detection of deep ore-controlling structure using remote sensing. International Multidisciplinary Scientific GeoConference Surveying Geology and Mining Ecology Management, (1), 113-118. https://doi.org/10.5593/sgem2015/b11/s1.015

[2] Baibatsha, A., Omarova, G., \& Shakirova, G. (2019). Innovative technologies of mineral resources predictioin on covered territories. International Multidisciplinary Scientific GeoConference Surveying Geology and Mining Ecology Management, (1), 271-278. https://doi.org/10.5593/sgem2019/1.1/s01.033

[3] Baibatsha, A., Dyussembayeva, K., \& Bekbotayeva, A. (2016). Study of tails enrichment factory Zhezkazgan as a technogenic ore deposits. International Multidisciplinary Scientific GeoConference Surveying Geology and Mining Ecology Management, (1), 579-586. https://doi.org/10.5593/sgem2016/b11/s01.073

[4] Baibatsha, A., Dussembayeva, K., Bekbotayeva, A., \& Abdullayeva, M.T. (2018). Tails of enrichment factories as the technogenic mineral resources. International Multidisciplinary Scientific GeoConference Surveying Geology and Mining Ecology Management, (1), 519-526. https://doi.org/10.5593/sgem2018/1.1/s01.066

[5] Zeilik, B., \& Seitmuratova, E. (1974). Meteoritic structure in Central Kazakhstan and its magma-ore-controlling role. Doklady Akademii Nauk SSSR, (218), 167-170.

[6] Zeǔlik, B. (1991). Udarno-vzryvnaia tektonika i kratkiiy ocherk tektoniki plit. Alma-Ata, Kazakhstan: Gylym, 120 s.

[7] Zeilik, B.S., \& Kadyrov, D.R. (2010). The new technology of forecasting mineral deposits based on remote sensing. $1^{\text {st }}$ EAGE International Geosciences Conference on Kazakhstan. https://doi.org/10.3997/22144609.20145707

[8] Seitmuratova, E.Yu., Zeylik, B.S., Dautbekov, D.O., \& Baratov, R.T. (2018). Forecast of metallic mineral resource deposits based on the principles of shock-explosive tectonics and use of the earth remote sensing data. News of National Academy of Sciences of the Republic of Kazakhstan, 6(432), 210-220. https://doi.org/10.32014/2018.2518-170x.51

[9] Zeilik, B. (2002). The Zeilik prospect area prediction method in search for metal deposits. Patent No. 12039, Republic of Kazakhstan.

[10] Sokolov, B., \& Starostin, V. (1997). Flyuidodinamicheskaya kontseptsiya obrazovaniya mestorozhdenii poleznykh iskopaemykh (uglevodorodnykh, metallicheskikh i nemetallicheskikh). Smirnovskii Sbornik, 99-147.

[11] Osinski, G.R., Lee, P., Parnell, J., Spray, J.G., \& Baron, M. (2005). A case study of impact-induced hydrothermal activity: The Haughton impact structure, Devon Island, Canadian High Arctic. Meteoritics \& Planetary Science, 40(12), 1859-1877. https://doi.org/10.1111/j.19455100.2005.tb00150.x

[12] Pirajno, F. (2005). Hydrothermal processes associated with meteorite impact structures: evidence from three Australian examples and implications for economic resources. Australian Journal of Earth Sciences, 52(4-5), 587-605. https://doi.org/10.1080/08120090500170468

[13] Saul, J. (2018). Circular scars dating to the Earth's accretionary period. Energy Procedia, (146), 12-16. https://doi.org/10.1016/j.egypro.2018.07.003

[14] Laverov, N. (2008). Izmenenie okruzhayuushhey sredy i klimata: prirodnye i svнazannye s nimi tehnogennye katastrofy. Moskva, Rossiya: IFZ RAN, $198 \mathrm{~s}$.

[15] Vishnevskiy, C. (2007). Astroblemy. Novosibirsk: Nonparel', 286 s.

[16] Kouda, R., \& Koide, H. (1978). Ring structures, resurgent cauldron, and ore deposits in the Hokuroku Volcanic Field, Northern Akita Japan. Mining Geology, 28(150), 233-244. https://doi.org/10.11456/shigenchishitsu1951.28.233

[17] Stazhevskii, S.B. (2004). Ring structures as a contribution to the genesis and stress-strain state of mineral deposits. Journal of Mining Science, 40(3), 259-264. https://doi.org/10.1007/s10913-005-0005-4

[18] Mamedov, E.A., Ahmed, E.S., \& Chiragov, M.I. (2013). Copper-GoldSulphide mineralization associated with late precambrian volcanic ring structures, Southern Sinai, Egypt. Arabian Journal for Science and Engineering, 39(1), 273-286. https://doi.org/10.1007/s13369-013-0854-0

[19] Winkler, R., Poelchau, M.H., Moser, S., \& Kenkmann, T. (2016). Subsurface deformation in hypervelocity cratering experiments into high-porosity tuffs. Meteoritics \& Planetary Science, 51(10), 18491870. https://doi.org/10.1111/maps.12694

[20] Schmieder, M., Seyfried, H., \& Gerel, O. (2013). The circular Uneged Uul structure (East Gobi Basin, Mongolia) - Geomorphic and structural evidence for meteorite impact into an unconsolidated coarse-clastic target? Journal of Asian Earth Sciences, (64), 58-76. https://doi.org/10.1016/j.jseaes.2012.11.042
[21] Korobeinikov, A.N., Mitrofanov, F.P., Gehor, S., Laajoki, K., Pavlov, V.P., \& Mamontov, V.P. (1998). Geology and copper sulphide mineralization of the Salmagorskii ring igneous complex, Kola Peninsula, NW Russia. Journal of Petrology, 39(11-12), 2033-2041. https://doi.org/10.1093/petroj/39.11-12.2033

[22] Kovalenko, V.I., \& Yarmolyuk, V.V. (1995). Endogenous rare metal ore formations and rare metal metallogeny of Mongolia. Economic Geology, 90(3), 520-529. https://doi.org/10.2113/gsecongeo.90.3.520

[23] Reimold, W.U., Koeberl, C., Gibson, R.L., \& Dressler, B.O. (2005). Economic mineral deposits in impact structures: A review. Impact Tectonics, 479-552. https://doi.org/10.1007/3-540-27548-7_20

[24] Gebhardt, A., Niessen, F., \& Kopsch, C. (2006). Central ring structure identified in one of the world's best-preserved impact craters. Geology, 34(3), 145. https://doi.org/10.1130/G22278.1

[25] Kovaleva, E., Huber, M.S., Roelofse, F., Tredoux, M., \& Praekelt, H. (2018). Pseudotachylite vein hosted by a clast in the Vredefort Granophyre: characterization, origin and relevance. South African Journal of Geology, 121(1), 51-68. https://doi.org/10.25131/sajg.121.0002

[26] Masaitis, V.L., Petrov, O.V., \& Naumov, M.V. (2018). Impact lithologies a key for reconstruction of rock-forming processes and a geological model of the Popigai crater, northern Siberia. Australian Journal of Earth Sciences, 66(1), 81-94. https://doi.org/10.1080/08120099.2018.1509372

[27] Zeilik, B.S., \& Baratov, R.T. (2016). Cosmic bombardment and the problem of protecting the planet to sustain life on Earth. News of the National Academy of Sciences of the Republic of Kazakhstan, Series of Geology and Technical Sciences, 2(416), 52-70.

[28] Kalybekov, T., Rysbekov, K.B., Toktarov, A.A., \& Otarbaev, O.M. (2019). Underground mine planning with regard to preparedness of mineral reserves. Mining Informational and Analytical Bulletin, (5), 34-43. https://doi.org/10.25018/0236-1493-2019-05-0-34-43

[29] Abdiev, A.R. (2002). Evaluation of the stressed-strained state of rock massif for brown coal deposit in Kara-Keche. Gornyi Zhurnal, (10), 70-72.

[30] Mendygaliyev, A., Arshamov, Y., Selezneva, V., Yazikov, E., \& Bekbotayeva, A. (2021). Prospects for application of multi-spectral earth sensing data in forecasting and searching for reservoir-infiltration uranium deposits. News of the National Academy of Sciences of the Republic of Kazakhstan, Series of Geology and Technical Sciences, 2(446), 90-97.

[31] Seitmuratova, E.Y., Goryaeva, V.S., Arshamov, Y.K., Baratov, R.T., Dautbekov, D.O., Saidasheva, F.F., \& Seitzhanov, S.A. (2019). Results of survey works on gold mineralization revaluation for the Zhungar-Balkhash fold belt. News of the National Academy of Sciences of the Republic of Kazakhstan, Series of Geology and Technical Sciences, 1(433), 206-215.

[32] Abdykaparov, C.M., \& Abdiev, A.R. (2002). State and prospects of the development the brown coal deposit in Kara-Keche. Gornyi Zhurnal, (10), 16-19.

[33] Glikson, A. (2018). Structure and origin of Australian ring and dome features with reference to the search for asteroid impact events. Tectonophysics, (722), 175-196. https://doi.org/10.1016/j.tecto.2017.11.003

[34] Glikson, A.Y., \& Pirajno, F. (2018). Ring and dome features, possible and probable impact structures. Modern Approaches in Solid Earth Sciences, 123-156. https://doi.org/10.1007/978-3-319-74545-9_5

[35] Schulz, T., Sackl, F., Fragner, E., Luguet, A., van Acken, D., \& Abate, B. (2020). The Zhamanshin impact structure, Kazakhstan: A comparative geochemical study of target rocks and impact glasses. Geochimica et Cosmochimica Acta, (268), 209-229. https://doi.org/10.1016/j.gca.2019.08.045

[36] Bekzhanov, G. (1996). Geologicheskaya karta Kazakhstana, masshtab 1:1000000. Almaty, Kazakhstan: Ministerstvo geologii i okhrany nedr Respubliki Kazakhstan.

[37] Baibatsha, A., Arshamov, Y., Bekbotayeva, A., \& Baratov, R. (2017) Geology of the main industrial types of copper ore deposits in Kazakhstan. International Multidisciplinary Scientific GeoConference Surveying Geology and Mining Ecology Management, (11), 231-238. https://doi.org/10.5593/sgem2017/11/s01.029

[38] Satpayeva, M. (2008). O mantiinykh plyumakh. O proyavleniyakh plyumov v poverkhnostnykh strukturakh i uchastkakh lokalizatsii orudeneniya. News of the National Academy of Sciences of the Republic of Kazakhstan, Series of Geology, (1), 15-24.

[39] Daukeev, S. (1997). Karta lokal'nykh anomalii sily tyazhesti Respubliki Kazakhstan 1:1000000 masshtaba. Almaty, Kazakhstan: Ministerstvo geologii i okhrany nedr Respubliki Kazakhstan.

[40] Uzhkenov, B., \& Nikitchenko, I. (2003). Karta poleznyh iskopaemyh Kazahstana, masshtab 1:1000000. Almaty, Kazakhstan: Ministerstvo energetiki i mineral'nykh resursov Respubliki Kazakhstan.

[41] Kozlovskii, E. (1982). Kosmogeologicheskaya karta SSSR. Masshtab 1: 2500000. Moskva, Rossiya: Aerogeologiya. 


\section{Нова технологія прогнозу родовищ корисних копалин для виділення перспективних площ у Жезказганському рудному районі}

\section{Б. Зейлік, Я. Аршамов, Р. Баратов, А. Бекботаєва}

Мета. Виявлення та прогноз перспективних площ Жезказганського рудного району для постановки детальних пошуковооціночних робіт за допомогою нової комплексної технології прогнозних побудов у геології родовищ корисних копалин.

Методика. Використано комплексний методичний підхід, що включає методи дешифрування матеріалів даних дистанційного зондування Землі (ДЗ3), застосування геофізичних даних і методи аналогії та актуалістичний. Всі побудови виконані відповідно до принципів ударно-вибухової тектоніки (УВТ). Прогнозні побудови починали з підбору даних Дз3 для досліджуваного регіону і дешифрування на основі обробки радіолокаційних космічних знімків зі супутника Radarsat-1. Обробка радіолокаційних космічних знімків здійснювалася в програмному комплексі Erdas Imagine.

Результати. Виділено нові локальні перспективні площі, в межах яких передбачається виявлення родовищ, запаси яких повинні заповнити виснажену рудну базу в районі міста Жезказган: площа гравітаційного максимуму 1 (Близький), що розглядається як найбільш перспективна та розташована в безпосередній близькості до міста Жезказган; площа гравітаційного максимуму 2 (Середній); площа, гравітаційного максимуму 3 (Далекий-Табилга); площа гравітаційного максимуму 6 (Центральний). Виявлено також перспективну площу, що перекрита чохлом пухких відкладень, розташована всередині Теректінської кільцевої структури, а також площу, що примикає до свердловини Ш-2, пробуреної на південь від родовища Жезказган і містить потужний пласт піритизованих сірих пісковиків.

Наукова новизна. Застосування нової технології прогнозування на відміну від відомих визначається широким використанням новітньої дистанційної інформації, що вилучається з космічних знімків і підвищує точність визначення перспективних площ родовищ.

Практична значимість. Нова технологія прогнозу родовищ корисних копалин дозволяє різко скорочувати площі, що підлягають першочерговому пошуку, та забезпечує значну економію коштів.

Ключові слова: прогноз, родовище корисних копалин, кільцеві космогенні структури, концентричні зони, блоки взаємного накладення, гравіметрія

\section{Новая технология прогноза месторождений полезных ископаемых для выделения перспективных площадей в Жезказганском рудном районе}

\section{Б. Зейлик, Я. Аршамов, Р. Баратов, А. Бекботаева}

Цель. Выявление и прогноз перспективных площадей Жезказганского рудного района для постановки детальных поисковооценочных работ с помощью новой комплексной технологий прогнозных построений в геологии месторождений полезных ископаемых.

Методика. Использован комплексный методический подход, включающий методы дешифрирования материалов данных дистанционного зондирования Земли (ДЗ3), применение геофизических данных и методы аналогии и актуалистический. Все построения выполнены в соответствии с принципами ударно-взрывной тектоники (УВТ). Прогнозные построения начинали с подбора данных ДЗ3 для исследуемого региона и дешифрирования на основе обработки радиолокационных космических снимков со спутника Radarsat-1. Обработка радиолокационных космических снимков осуществлялась в программном комплексе Erdas Imagine.

Результаты. Выделены новые локальные перспективные площади, в пределах которых предполагается обнаружение месторождений, запасы которых должны восполнить истощенную рудную базу в районе города Жезказган: площадь гравитационного максимума 1 (Ближний), рассматриваемую, как наиболее перспективную, расположенную в непосредственной близости к городу Жезказгану; площадь гравитационного максимума 2 (Средний); площадь, гравитационного максимума 3 (Дальний-Табылга); площадь гравитационного максимума 6 (Центральный). Выявлена также перспективная площадь, перекрытая чехлом рыхлых осадков, расположенная внутри Теректинской кольцевой структуры, а также площадь, примыкающая к скважине Ш-2, пробуренной южнее месторождения Жезказган имеющая мощный пласт пиритизированных серых песчаников.

Научная новизна. Применение новой технологии прогнозирования в отличие от известных определяется широким использованием новейшей дистанционной информации, извлекаемой из космических снимков, что повышает точность определения перспективных площадей месторождений.

Практическая значимость. Новая технология прогноза месторождений полезных ископаемых позволяет резко сокращать площади, подлежащие первоочередному поиску, что обеспечивает значительную экономию средств.

Ключевые слова: прогноз месторождений полезных ископаемых, кольцевые космогенные структуры, концентрические зоны, блоки взаимного наложения, гравиметрия 